"Customer's perception towards product quality of automotive SMEs operating in Metropolitan areas, and consideration of environmental impact"

\begin{tabular}{|c|c|}
\hline AUTHORS & $\begin{array}{l}\text { Lawrence Mpele Lekhanya (D https://orcid.org/0000-0002-9104-963X } \\
\text { Henry Lucky Dlamini }\end{array}$ \\
\hline ARTICLE INFO & $\begin{array}{l}\text { Lawrence Mpele Lekhanya and Henry Lucky Dlamini (2017). Customer's } \\
\text { perception towards product quality of automotive SMEs operating in Metropolitan } \\
\text { areas, and consideration of environmental impact. Environmental Economics, } \\
\text { 8(1), 36-45. doi:10.21511/ee.08(1).2017.04 }\end{array}$ \\
\hline DOI & http://dx.doi.org/10.21511/ee.08(1).2017.04 \\
\hline \multirow[t]{2}{*}{ RELEASED ON } & Saturday, 08 April 2017 \\
\hline & $($ (c) $)$ EY-NC \\
\hline LICENSE & $\begin{array}{l}\text { This work is licensed under a Creative Commons Attribution-NonCommercial } 4.0 \\
\text { International License }\end{array}$ \\
\hline JOURNAL & "Environmental Economics" \\
\hline ISSN PRINT & $1998-6041$ \\
\hline ISSN ONLINE & $1998-605 X$ \\
\hline PUBLISHER & LLC "Consulting Publishing Company "Business Perspectives" \\
\hline FOUNDER & LLC "Consulting Publishing Company "Business Perspectives" \\
\hline & 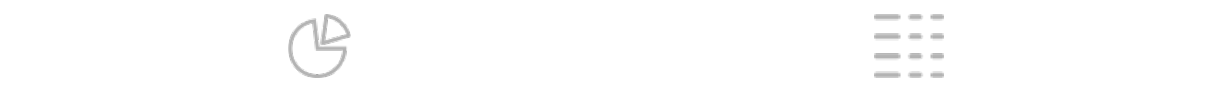 \\
\hline NUMBER OF REFERENCES & NUMBER OF FIGURES \\
\hline 20 & 0 \\
\hline
\end{tabular}

(C) The author(s) 2023. This publication is an open access article. 
Lawrence Mpele Lekhanya (South Africa), Henry Lucky Dlamini (South Africa)

\title{
Customer's perception towards product quality of automotive SMEs operating in Metropolitan areas, and consideration of environmental impact
}

\begin{abstract}
This paper examines customer's perception towards product quality of automotive SMEs operating in the Durban metropolitan areas and identifies how small and medium enterprises (SMEs) in South Africa (SA) contribute significantly to job creation, wealth, social stability, economic growth and reduction of poverty. Product quality of automotive SMEs requires serious attention, as it can have ecological environmental impact leading to the negative economic growth contributed by the industry. The study is aimed to understand the factors affecting automotive SMEs in order to help entrepreneurs to improve product quality and examining the customer's perception towards product quality. The sample size of the study was 120 SMEs selected using convenience sampling with respondents completing the questionnaire. A combined method of both quantitative and qualitative techniques was employed, while the analysis of data was done using the Statistics Package for Social Scientists (SPSS) version 23.0. The findings of the study revealed that lack of managerial skills and development negatively compromises product quality of the automotive sector. Also the results indicate that the absence of financial support from financial institutions delays the improvement of stock in the business, as this is an obstacle resulting in the unsustainability of the SMEs. Further research with larger samples and the consideration of other cities is recommended.
\end{abstract}

Keywords: small and medium enterprises (SME), automotive SMEs, environmental impact, customer's perception, product quality, South Africa, Durban metropolitan areas.

JEL Classification: M31, Q57, L15, L25.

\section{Introduction}

Small and medium enterprises are the engine of any country's economic development and they play a vital role for providing employment opportunities (Marnewick, 2014, p. 1). However, the Republic of South Africa and Ghana are the most successful countries in Africa, which play a significant role in economic growth development in the SMEs (Olawale and Garwe, 2010, p. 729). Therefore, it is noted that Ghana has established $92 \%$ of businesses and created $85 \%$ of job opportunities for the people of Ghana and also contributed $70 \%$ to the Gross Domestic Product (GDP), whereas the Republic of South Africa has established $91 \%$ of businesses and created $61 \%$ of job opportunities for the people of South Africa and also contributed 52\%-57\% to the GDP (Abor and Quartey, 2010, p. 218).

However, the SMEs believed supplying the word-ofmouth in order to examine the customer's perception towards product quality and it has become a great influence on examining customer's products (Doh and Hwang, 2009, p. 193). Furthermore, Moslehpour, Aulia and Masarie (2015, p. 67) concluded that

(C) Lawrence Mpele Lekhanya, Henry Lucky Dlamini, 2017.

Lawrence Mpele Lekhanya, Department of Public management \& Economics, Durban University of Technology, South Africa.

Henry Lucky Dlamini, Department of Entrepreneurial Studies and Management, Durban University of Technology, South Africa.

This is an Open Access article, distributed under the terms of the Creative Commons Attribution-NonCommercial 4.0 International license, which permits re-use, distribution, and reproduction, provided the materials aren't used for commercial purposes and the original work is properly cited. customer satisfaction is the core key challenge to the SMEs, because customers are very sensitive when it comes to product quality and price. The price of a product is playing a very important role in the customers' perceptions. Lamb, Hair, McDaniel, Boshoff, and Terblanche (2008, p. 76) added that customers are using five senses (sight, smell, taste, touch and hearing) to describe a product.

Therefore, the overall aim of the study was to explore the factors influencing customer's perceptions toward product quality of automotive SMEs operating in Durban metropolitan areas.

This overall aim is guided by the following research objectives:

- to examine the customer's perceptions towards products quality of automotive SME's operating in the Durban metropolitan areas;

- to identify and discuss factors affecting automotive SME's operating in the Durban metropolitan areas.

\section{Literature review}

1.1. SMEs and Durban metropolitan definition. There is indeed a need to clarify the definitions of the following terms, which are found in the body of the study, which is small enterprise and medium enterprise. The definitions will be dependent on the countries, regions and economic sector. Abor and Quartey (2010) support the above statement that the industrialized countries and developing countries have given a different definition of the small and medium enterprise. The SMEs definition is a major concern in the literature because many authors have given 
different definitions. Some authors looked at the size, turnover level, number of employees and GDP contribution among firms. However, if the contribution to the GDP is small, it's regarded as a small firm, but if the contribution is big it is regarded as a large firm. Nevertheless, Abor and Quartey (2010) also believe that there is no general agreement on the SMEs definition; the definition depends on the country concerned and on the criteria they follow to meet requirement. According to the National Small Business Amendment Act (26 of 2003), business is simply classified into the different types of enterprises:

- micro enterprise;

- very small enterprise;

- small enterprise; and

- medium enterprise.

However, the term "Durban" is simply defined as a coastal metropolitan area, which is situated on the east coast of South Africa in the Province of KwaZulu Natal (Breetzke, 2009, p. 3). After Johannesburg, Durban is the second biggest city within South Africa. Therefore, the eThekwini Municipality Integrated Development Plan (2012/2013 to 2016/2017) indicated that Durban has an extremely large population size, which has grown by an average of $1.13 \%$ p.a. Statistics South Africa (2014, p. 20) states that the Durban population will be estimated at 3.64 million people between the year 2016 and 2017. Furthermore, Statistics South Africa $(2014$, p. 3) added that the population in South Africa has been projected at 54 million people. Marnewick (2014, p. 2) indicated that South Africa has a large population and the rate of unemployment, which is standing at $24.5 \%$, is too high. He also believes that the creation of SMEs will remedy this situation to a large extent. Olawale and Garwe (2010, p. 729) and Abar and Quartey (2010, p. 218) support the idea that the creation of SMEs will play a vital role for the economic growth and development of the people of South Africa and will also play a critical part in poverty reduction.

\subsection{Customer's perception definition.} Perception is defined as a broad imagination that people create in their mind and interpret that imagination as a bigger meaningful picture (Raji and Zainal, 2016, p. 59). However, customer creates an image of that product based on the value of the product. Sometimes they say the value is low price; value is whatever customers want in a product; value is the quality customers get at the price paid, and value is what customer gets for what they give. Therefore, Amin, Falk, and Schhmitt (2014, p. 391) state that the customer perception has been generated at the first impression about the product, however, the customers form a judgement about the value of a product immediately before purchasing. In addition, the customer perception is prejudiced by the experience already received with the similar product. Hence, Rani (2014, p. 52) agrees that judgement is a process like buying behavior whereby customers try to understand the product and scrutinize it up until getting on the right track or making a decision to buy or not to buy.

1.3. Automotive SMEs sector in South Africa. SMEs are of fundamental importance to many economies, although South Africa has been described as a country where poverty is high. In this regard, literature states that the SME is the key engine of economic development and creates almost half of the jobs in the economy. However, South Africa is characterized by poverty and unemployment rates. It is noted in a previous study that South Africa lagged behind other developing countries in economic development. Manyaka (2015, p. 3) adds that behind an SME, there is an entrepreneur, who has a desire to accept responsibility for solving a problem, setting goals and reaching goals through their own efforts, desire to apply his knowledge of skills in his business and a desire to have an outcome for the decision he made. Automotive SME in this study is a sector that sells vehicle parts or components to the customers of the Durban metropolitan area. A car part is the smallest removable item on a car, whereas a component is a term frequently used when referring to an electrical or electronic part. The aim of the automotive SMEs in this car production is to fulfil the requirements of the customer such as short delivery, low cost and quality product (Ryu, Shin, Lee and Choi, 2008, p. 253).

1.4. Importance of medium communication in the SMEs. Social media plays a very big role in the SMEs, whether it is negative or positive, it impacts on the customers of the SMEs. Duffett and Wakeham $(2015$, p. 20) state that the spreading of social media to the people of South Africa is increasing, although it is not more than a decade old. They continue by revealing that social media has increased from $10 \%$ in 2010 and 35\% in 2012. Rudansky-Kloppers (2014, p. 1187) argues that the social media has benefited only $30 \%$ in 2012 , and South Africa is sitting on 14 million users. It was about $25 \%$ in 2010 and is sitting on 8.5 million people of South Africa, who fully engage themselves on social media. The media communication is very useful, more especially, to the marketers of the SMEs, because when marketing on media communication, the message quickly reaches the customers. 
Marketing communication enables social media to generate the sales in order to survive in their SMEs. Most people are relying on medium communication and expect that media will give exactly what they are expected to see and feel. Sometimes social media create an attitude in other customers for using an inferior brand rather than using a superior brand in terms of cost effectivity (Schinski and Dabrowski, 2013). However, social media apparently give the customer the opportunity to degrade the product of other competitors in the market. An interaction of customers over social media is affecting customer buying behavior and their choice of automotive SMEs.

\subsection{Importance of automotive SMEs in South Africa. Industry Policy Action Plan (IPAP) of $2007 / 2008$ indicated that automotive sector is playing an important role in the economy of South Africa; this sector contributes almost $7 \%$ to the GDP of South Africa.}

Sithole (2015, p. 13) and Marnewick (2014, p. 1) revealed that the mission of the development of SMEs in South Africa is to play an incredible role in sustainable poverty reduction, economic growth and massive job creation within the community of South Africa. Therefore, automotive SME's role in this study is to supply motor parts to their customers, because they supply them for a cheaper price than the dealership. Rose, Deros, Rahman, and Nordin (2011, p. 872) state that the development of automotive SMEs is considered as a strategic weapon in a competitive market with an increasing demand for quality products. Withers, Garza-Reyes, Kumar, and Rocha-Lona (2013, p.134) support the fact that the competitive market has been increased not only due to large companies, but also automotive SMEs are leading in a competitive market, which facilitates the improvement of operations and the shaping of product quality as a platform of the business.

SMEs in South Africa are the building blocks of an economy, whereby SMEs contribute $61 \%$ to the country's employment statistics (Khan, 2014). However, Mayatra, Chauham, Trivedi, and Qureshi (2016, p. 1) illustrate that development of automotive SMEs that will manufacture small components like auto parts is saving much time, and the economy is rapidly growing at the same time. Deros, Yusof, and Salleh (2006, p. 399) continue support that automotive SMEs have beautiful characteristics, because they supply components to the larger companies at the cheapest price, their communication is very fast, decision-making process is quick and implementation is fast.
1.6. Product quality. The product quality is considered as one of the factors that, as an effect, stimulate the customer perception. Sarwar, Azam, Haque, Sleman, and Nikhashemi (2013) state that the buying power of the Chinese product is growing rapidly throughout the entire world, although some customers are not buying Chinese products because of quality issues. The product quality is the key issue for the customers - they believe in purchasing a product that will last long. The product quality must always exceed the customer's expectation, because the standard of an enterprise is determined by the customer who has experienced that product and uses that experience and feeling to form a judgement against business (Abdullah and Rozario, 2009). Tsele and Tulo (2015) believe in supplying good products to the customers and also believe that if the customers trust the product quality, they will be loyal to that product even when tough times (recession) come. They will always stand up for that product, because it good and reliable.

1.7. Price offer. Customers believe using price as a measurement or indicator of product quality (Agyekum, Haifeng, and Agyeiwaa, 2015, p. 25). Price is a marketing communication tool that conveys a message to the customers for the product and influence to speed up decision making process (Erdil, 2015). However, price transparency should lead directly to price fairness perceptions, which, in turn, have significant impacts on satisfaction. Therefore, it is important to build the customer loyalty toward the product, because the customer will repeat purchasing the product with any price offered on the table (Spence and Essoussi, 2008).

1.8. Place (country of origin). Developed countries prefer to buy their own products, which they still continue exercising ethnocentrism and they also believe that country's image is playing an important role to the consumers (Jahanshabi, Gashti, Mirdamadi, Nawaser, and Khaksar, 2011). Frank,Torrico, Enkawa, and Schvaneveldt (2014) have confidence in that investment in product quality because of its pay off in a long term to the developed countries. They further elaborate that consumers do often assume that the developed country products are of better quality than the product from developing countries.

1.9. Promotion. Promotion is playing a vital role in any developed or developing country, because promotion is one of the driving components for economic growth. Promotion is a wakeup call or booster of the consumers to keep recognizing the product that is still available in the market with additional features and it performs better than before with a high performance standard, this is a 
way of selling the business. Therefore, there is a relationship between product quality, price, place and promotion in this study. The study reveals that promotion is a factor that influences the customers' perception (Singh, 2012). Promotion consists of different blends of its components which are used to achieve the business' marketing goal.

1.10. Internal factors. In this study, there are a number of factors that affect the performance of small and medium enterprise in the automotive sector of Durban in South Africa. However, those numbers of internal factors contribute to the failure of the automotive SMEs. It is noted and acknowledged that the SMEs are the backbone of most economies and are a key source of economic development of any country. Kambwale, Chisoro, and Karodia (2015) highlighted the fact that there are some significant factors that contribute to the SMEs to decline.

1.11. Poor managerial skills. Skill and knowledge belong to important factors of production, upon which SMEs development is currently formatted and, as a result, stimulates economic development in the developing country (Papulova and Mokros, 2007). Bouazza, Ardjouman, and Abada (2015, pp. 101-103) establish that poor managerial skills is a very sensitive and serious factor in the SMEs; it will affect the product quality with the result that the external factor will intervene in this situation. However, external factors like financial institution will not assist the SMEs in terms of performance that resulted through poor managerial skills. Quality management practice is an overall remedy that will deliver the best product quality to the SMEs customers (Dash and Tripathy, 2016, p. 14).

1.12. Lack of financial support. Globally, SMEs are regarded as an economic development sector, creator of an employment platform, and finally, a fighter for poverty. However, various studies indicated that formal SMEs have contributed almost $45 \%$ to total employment and 33\% to the Gross Domestic Product. Therefore, SMEs are less likely to be able to secure a bank loan than large enterprises. Instead, they rely on their personal funds. Fauad (2013) reveals that more than $50 \%$ of the SMEs are facing a problem of getting financial support from financial institutions in order to improve their SME's development. However, this limitation of financial support leads to the decline of the SMEs in most cases. Mbawuni and Nimako (2015, p. 63) add that it is difficult to give new SMEs external finance, because most SMEs easily fail within a short period of time in a business and, then, the business will not return any profit. Veerappan and Sathishkumar (2016) report that profit is the measure of success of fruitful SMEs, and it is regarded an essential product of the business.
1.13. Poor planning, organizing, leading and controlling. Entrepreneurship is about developing a business from scratch, while managing scarce resources such as time, money, etc. Therefore, it is better to plan, organize, lead and control as much as possible with limited resources. Entrepreneurs fail to plan because of their ignorance and lack of vision about their business. Lekhanya (2010, p. 39) states that SMEs fail when they were still at the starting stage simply because of poor planning in estimating a cost of starting and running the SME. Khan, Khan, and Khan (2011) state that training given to staff will yield a good performance on their SMEs, and the product will perform well in the market. Training is an important factor that gives the SME a good platform, as all SMEs are willing to achieve a goal through properly planning, organizing, leading and controlling. Gibbert, Leibold, and Probst (2002, p. 459) support that knowledge is a key competitive factor both locally and globally by organizing the employees to be a powerful body in the SMEs by having the training to know how to deal with Customer Knowledge Management (CKM). Employees must have the ability to know how to screen the customers about how they feel about a product offered by their SMEs. As mentioned by Vallabh, Radder, and Venter (2015), the creation of the SME is to meet customer needs and, if needs are met, the customers' perception will start to be established.

\section{Research methodology}

Both qualitative and quantitative methods were used for data collection. However, the questionnaires were containing both closed-ended and open-ended questions and dispensed to the 120 SMEs owners/managers.

2.1. Target population. The target population of this study was SMEs located around Durban metropolitan areas, as this was the target population in this study.

2.2. Sampling. Convenience sampling has been applied in this study, because populations were easily available to the researcher and the non-probability technique was used, because it is cheaper than probability sampling and can be implemented more quickly (Leiner, 2014, p. 4). Therefore, in this study, the researcher selected Durban metropolitan areas, which include Durban North, Durban South and Durban Central, where questionnaires were distributed to the automotive SMEs.

2.3. Measurement instrument. The measuring instrument in this research was a questionnaire composed together with a closed-ended question and opened-ended question, five (5) point Likert scale rating. The respondents were also given enough blank lines to elaborate their answers to the question asked in their questionnaire to give supplementary information. 
The questionnaire was compiled based on the research objectives of the study.

\subsection{Summary of quantitative method (closed- ended questions).}

- Gender

- Age

- Race group

- Level of education

\subsection{Summary of qualitative method (Open- ended questions) - short questions.}

1 What exactly are the customers' perceptions towards product quality in your business?

3. How often does your business offer staff training and scheduled meetings?

4. Does your business involve customers in new product planning?

Table 1. Summary of Likert scale

\begin{tabular}{|c|c|c|c|c|c|}
\hline $\begin{array}{l}\text { Statements on } \\
\text { customer's } \\
\text { perceptions }\end{array}$ & $\begin{array}{l}\text { Strongly } \\
\text { agree }\end{array}$ & Agree & Neutral & Disagree & $\begin{array}{l}\text { Strongly } \\
\text { disagree }\end{array}$ \\
\hline $\begin{array}{l}\text { Does the } \\
\text { consumer's } \\
\text { perception solve } \\
\text { the problem of } \\
\text { dissatisfaction with } \\
\text { a product? }\end{array}$ & & & & & \\
\hline $\begin{array}{l}\text { Do you think the } \\
\text { consumer's } \\
\text { perceptions put } \\
\text { more pressure on } \\
\text { competition? }\end{array}$ & & & & & \\
\hline $\begin{array}{l}\text { Do you think } \\
\text { customers' } \\
\text { perceptions can } \\
\text { drive the } \\
\text { automotive } \\
\text { business to } \\
\text { become } \\
\text { successful? }\end{array}$ & & & & & \\
\hline $\begin{array}{l}\text { Do you think } \\
\text { customers' } \\
\text { perceptions can } \\
\text { promote certain } \\
\text { religions to benefit } \\
\text { in a business? }\end{array}$ & & & & & \\
\hline
\end{tabular}

2.6. Data analysis. The information acquired was captured using the Statistic Package for Social Sciences (SPSS) version 23.0. Data captured were twice verified for possible errors. The result will be demonstrated through the use of tables and graphs in the text. Descriptive and inferential statistics will be used to analyze the data gathered. Statistical solutions refer to correlations as a bi-variate analyzis that measures the dominance of a relationship between variables being investigated.
2.7. Data collection. Data were collected using personally administered questionnaires. The researcher distributed 120 questionnaires over the period of one month across the various Durban metropolitan areas mentioned above (01 September 2016 - 30 September 2016).

2.8. Validity and reliability. Validation was considered in order to minimize errors that may have occurred during data capturing. The Cronbach alpha coefficient was used as a test of internal consistency and was frequently used to calculate the correlation values among the answers on the assessment tools. The achievement result of Cronbach alpha coefficient was 0.658 , thus, concluding that the reliability of the study was accepted.

\section{Discussion of findings}

Table 2. Provincial distribution in 2015

\begin{tabular}{|l|c|c|c|c|}
\hline \multicolumn{1}{|c|}{ Province } & $\begin{array}{c}\text { Formal } \\
\text { SMEs }\end{array}$ & $\begin{array}{c}\text { Informal } \\
\text { SMEs }\end{array}$ & Other & Total \\
\hline Western Cape & 110107 & 110188 & 10030 & 230324 \\
\hline Eastern Cape & 50670 & 141739 & 4957 & 197366 \\
\hline Northern Cape & 8534 & 9058 & 3019 & 20611 \\
\hline Free State & 26224 & 60816 & 9806 & 96846 \\
\hline KwaZulu Natal & 74976 & 283165 & 15293 & 373434 \\
\hline North West & 27430 & 79153 & 6273 & 112856 \\
\hline Gauteng & 306231 & 465100 & 13989 & 785321 \\
\hline Mpumalanga & 35208 & 141129 & 9063 & 185399 \\
\hline Limpompo & 28663 & 207512 & 14098 & 249663 \\
\hline TOTAL & 66433 & 1497860 & 86528 & 2251821 \\
\hline
\end{tabular}

Source: The Small Enterprise Development Agents (2016).

Table 3. Empirical finding/result for this study in 2016

\begin{tabular}{|l|l|}
\hline Product status & \multicolumn{1}{c|}{ Effects } \\
\hline Poor & $\begin{array}{l}\text { The findings of the study clear emphasize that 45.9\% } \\
\text { respondents agree that poor product influences bad } \\
\text { economic growth in the environment and also impacts } \\
\text { health risk to the society. Even though the automotive is } \\
\text { very competitive, many excellent management practices } \\
\text { are already in use in the industry. It is noticeable that an } \\
\text { ecological effect in this study is an effect that influences } \\
\text { the bad environment in the living society of Durban } \\
\text { metropolitan areas. However, the adoption of an informal } \\
\text { automotive SME is the main obstacle to the sustainable } \\
\text { economic growth in the City of Durban. Therefore, the } \\
\text { business environment has changed over the past few } \\
\text { years. However, Naude (2013, p. 408) also confirms that } \\
\text { the automotive company is under severe pressure and } \\
\text { faces many supply-chain problems that are a result of } \\
\text { rapid developments in supply-chain management, } \\
\text { technology advancements, high labor cost, poor } \\
\text { infrastructure, globalization and increasingly demanding } \\
\text { customers who are squeezing their suppliers on price and } \\
\text { non-price factors. The above problems also disturb the } \\
\text { growth of the economic environment within the country. }\end{array}$ \\
\hline
\end{tabular}




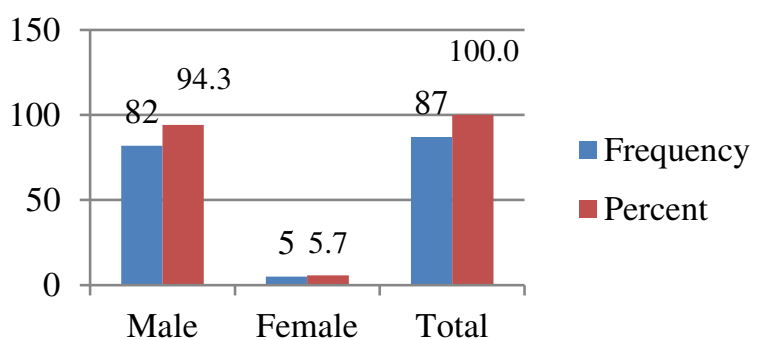

Fig. 1. Gender of participants

Figure 1 shows that 94.3 percent of the respondents were male and 55.7 percent were female. Overall, the ratio of males to females is approximately 9:1 (94.3\%: $5.7 \%$ ). However, the $\mathrm{df}=1$ and $\mathrm{p}=.000$ and this implies that there is a significant difference in the gender. Therefore, the hypothesis on this variable is accepted.

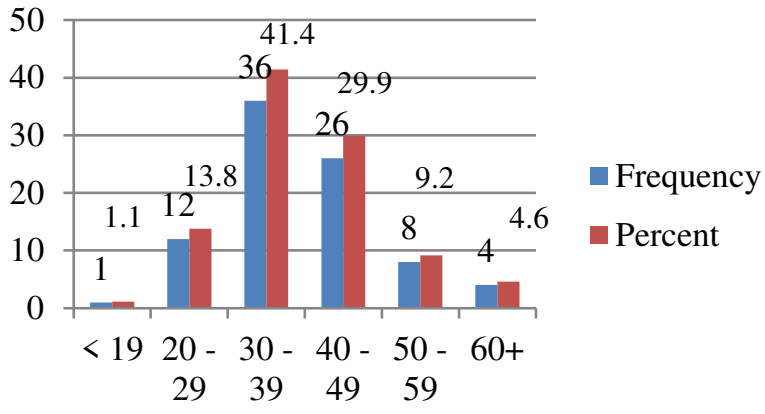

Fig. 2. Age of participants

Figure 2 shows that the lowest number of 1 (1.1 percent) of the participants was less than 19 years old, while 12 (13.8 percent) were from 20-29 years. Participants between the ages of 30-39 were 36 (41.4 percent) of respondents, while participants between age of 40-49 were 26 (29.9 percent), then, the respondents between the age of 50-59 were $8(9.2$ percent) and age of 60 or more were 4 (4.6 percentage). The participants at the age of 30-39 were the most keen to participate in the study, and this shows the positive changes moving forward in the automotive industry in the Durban metropolitan area. However, the $\mathrm{df}=5$ and $\mathrm{p}=.000$ implies that there is a significant difference in the age grouping. Therefore, the hypothesis on this variable is accepted.

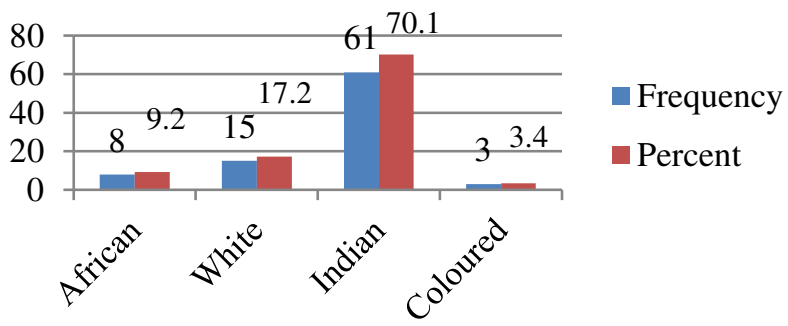

Fig. 3. Race group of participants

Figure 3 shows that 8 (9.2 percent) the participants were African, while 15 (17.2 percent) were White group participants. The highest number was Indian participants who contributed 61 (70.1 percent), followed by 3 (3.4 percent), which were Coloured participants. The Chi square test is used. However, the $\mathrm{df}=3$ and $\mathrm{p}=.000$ and this implies that there is a significant difference in the race grouping. Therefore, the hypothesis on this variable is accepted.

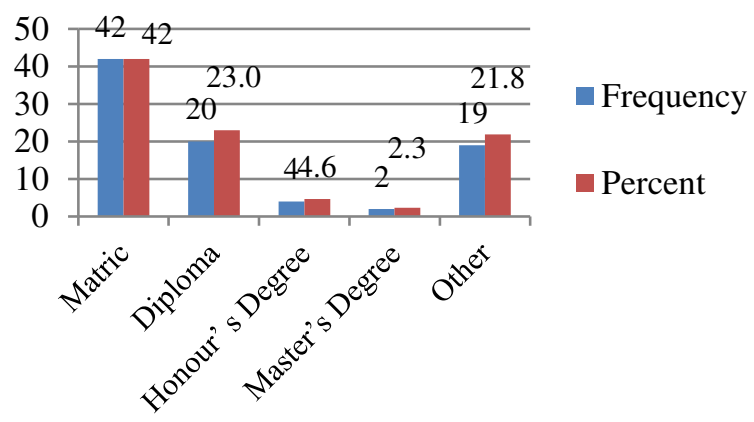

Fig. 4. Level of education of participants

Figure 4 above determines that 42 participants (48.3 percent) were in possession of Matric, followed by 20 (23 percent) who had a Diploma. Furthermore, 4 (4.6 percent) were in the possession of Honour's Degrees followed by 2 (2.3 percent) who had a Master's Degree. Those in possession of any qualification not listed above (Other) were 19 (21.8 percent). The Chi square test is used. Meanwhile, the $\mathrm{df}=4$ and $\mathrm{p}=.000$, however, this implies that the distribution by qualification is not similar. Therefore, the hypothesis on this variable is accepted.

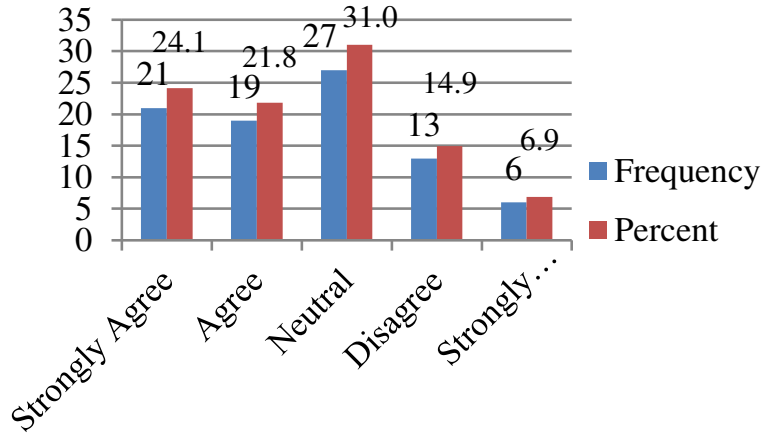

Fig. 5. Respondent's perception on product can solve the problem of dissatisfaction

Figure 5 indicates that the majority of respondents 27 (31 percent) were neutral that the customer's perception can solve the problem of dissatisfaction with a product. Meanwhile, 21 (24.1 percent) strongly agreed with this statement, 19 (21.8 percent) of the respondents just agreed, while 13 (14.9) disagreed and 6 (6.9 percent) strongly disagreed. However, the $\mathrm{df}=4$ and $\mathrm{p}=.000$ ) finding shows a significant relationship between the variables. Therefore, the hypothesis on this variable is accepted. 


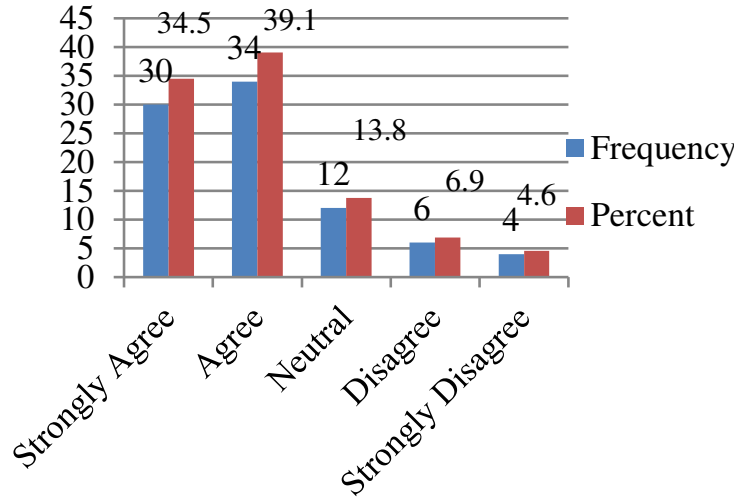

Fig. 6. Respondent's perception on competition can put more pressure

Figure 6 indicates that the majority of respondents 34 (39.1 percent) agreed that the customer's perception puts more pressure on the competition. Meanwhile, 30 (34.5 percent) strongly agreed with this statement, 12 (13.8 percent) of the respondents were neutral, while 6 (6.9 percent) disagreed and 4 (4.6 percent) strongly disagreed. However, the df $=4$ and $p=.000$. Therefore, the hypothesis on this variable is accepted.

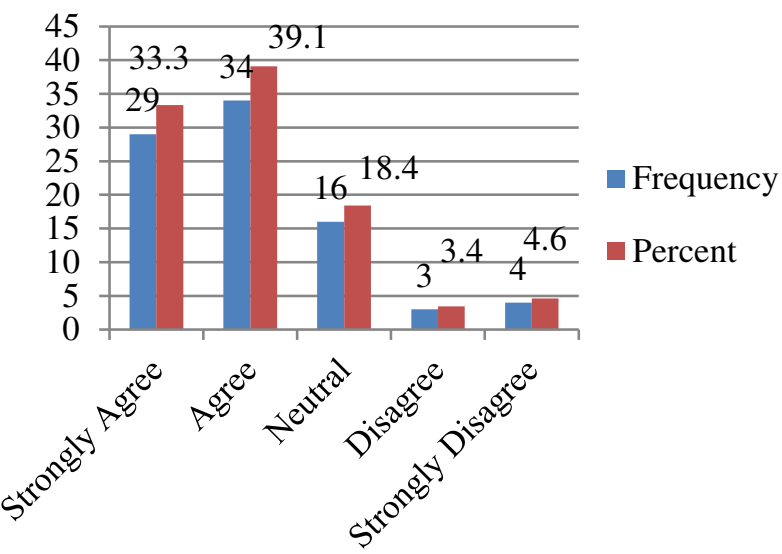

Fig. 7. Respondent's perception can drive the automotive business to become successful

Figure 7 indicates that the majority of respondents 34 (39.1 percent) agreed that the customer's perception can drive automotive business to become successful. Meanwhile, 29 (33.3 percent) strongly agreed with this statement, 16 (18.4 percent) of the respondents were neutral, while 4 (4.6) strongly disagreed and 3 (3.4 percent) disagreed. However, the $\mathrm{df}=4$ and $\mathrm{p}=.000$ ) finding shows a significant relationship between the variables. Therefore, the hypothesis on this variable is accepted.

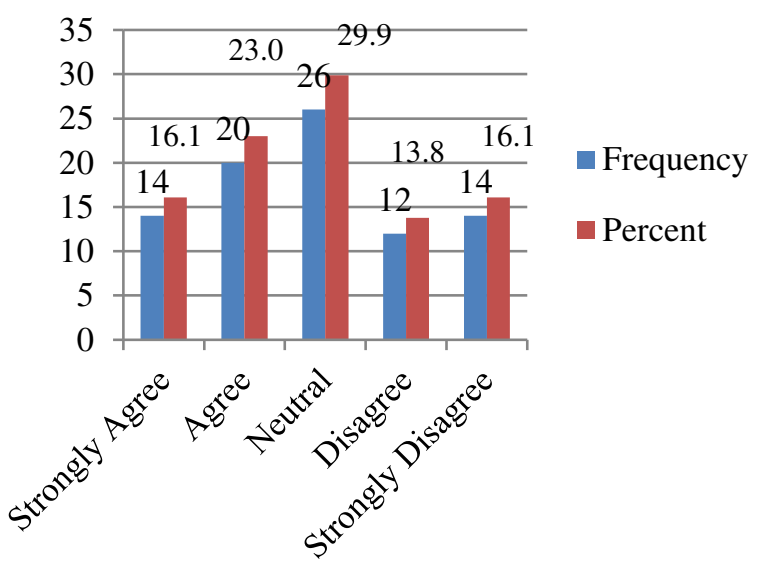

Fig. 8. Respondent's perception of influence religions

Figure 8 indicates that the majority of respondents 26 (29.9 percent) were neutral regarding the statement that the customer's perception can promote certain religions to benefit in a business. Meanwhile, 20 (23 percent) strongly agreed with this statement, 14 (16.1 percent) of the respondents strongly agreed, while 14 (16.1) strongly disagreed and 12 (13.8 percent) just disagreed. However, the $\mathrm{df}=4$ and $\mathrm{p}=.102$ finding shows no significant relationship between the of variables. Therefore, the hypothesis in this variable is not accepted.

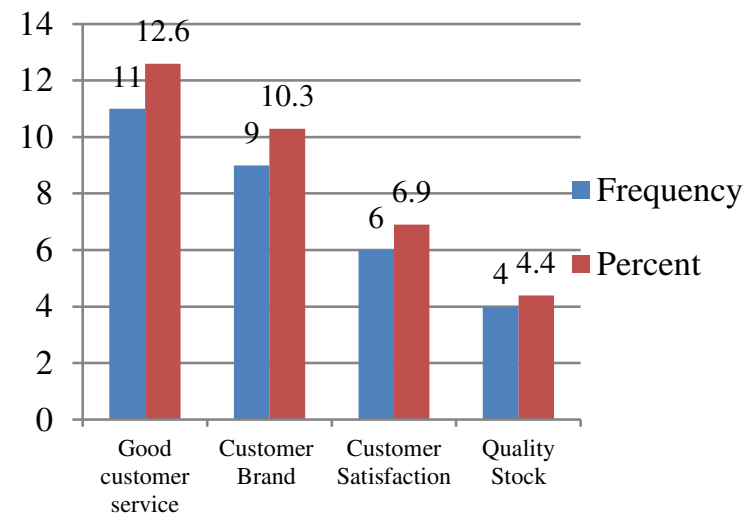

Fig. 9. Respondents about customer 's perception towards product quality in you business?

It is evident that, with 11 (12.6 percent) of respondents indicating their ability to get good customer service, this is the factor that has encouraged them to keep buying the product. A total of 9 (10.3 percent) of respondents showed that customer brand is good for the business, while 6 (6.9 percent) of respondents showed that customer satisfaction is good and 4 (4.04 percent) showed that the customers are willing to buy quality stock. 


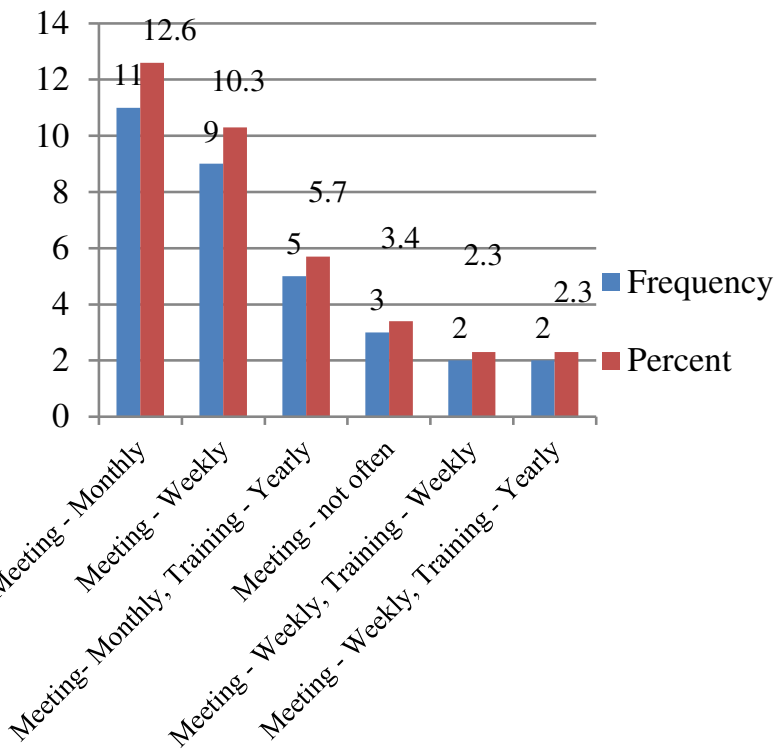

Fig. 10. Respondents about staff training and scheduled meeting?

The results show 11 (12.6 percent) respondents that scheduled a meeting once a month. Meanwhile, 9 (10.3 percent) scheduled a meeting every week, while 3 (3.4) did not schedule meetings often. Furthermore, 2 (2.3 percent) of the respondents scheduled meeting weekly and offer training weekly as well and 2 (2.3 percent) of the respondents scheduled meeting every week and offer training once a year.

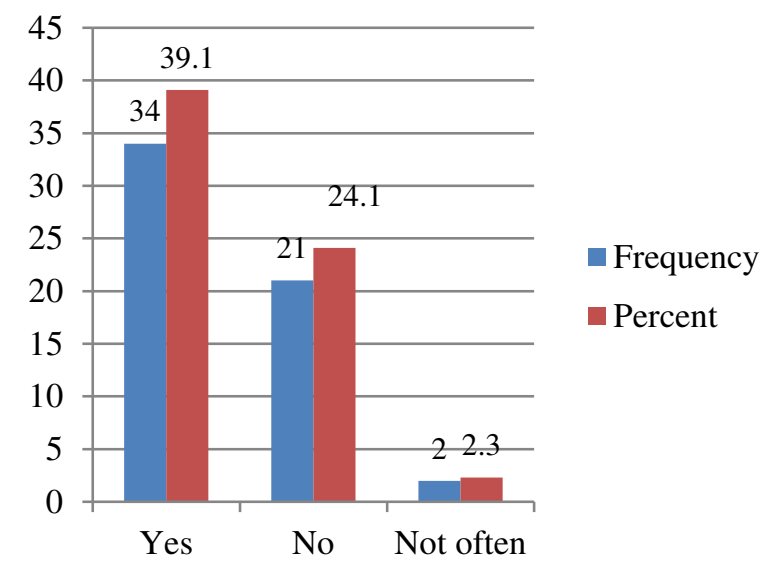

Fig. 11. Respondents abkout customer involvement in a new product planning.

The findings on this statement indicated that 34 (39.1 percent) the respondents indicated 'yes' that they will involve the customers in new product planning. However, 21 (24.1 percent) respondents indicated 'No' and 2 (2.3 percent) respondents did 'Not often' involve customers in new product planning.

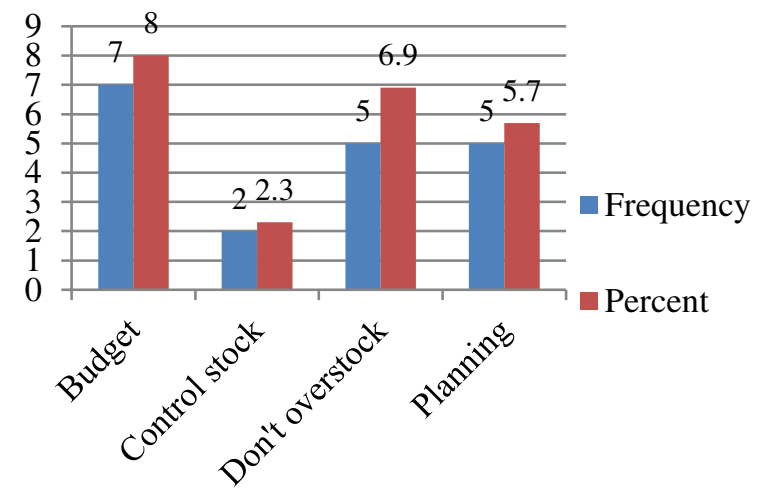

Fig. 12. What advice do you give other SMEs to avoid from financial crisis?

The findings show that 7 ( 8 percent) the respondents indicated that to budget properly will avoid financial crises in SMEs. However, 2 (2.3 percent) respondents indicated that the SMEs must exercise stock control , while 5 (6.9 percent) indicated that SMEs must avoid overstocking and 5 (5.7 percent) indicated that the SMEs must accurately plan for the future.

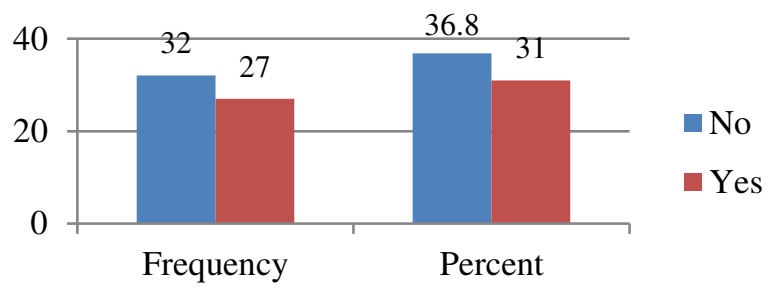

Fig. 13. Does your business have a customer care service hot-line?

The findings revealed that 32 (36 percent) respondents indicated 'no' that they do not have customer care service hot-line and 27 (31 percent) respondents indicated 'yes' they do have customer care service hot-line.

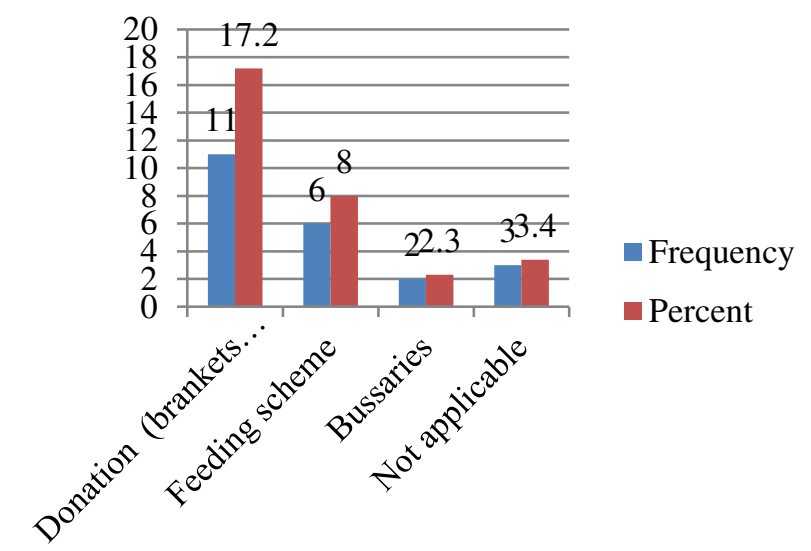

Fig. 14. Give any view on how your business engages in community outreach? 
The results reveal that 11 (17.1 percent) respondents indicated that their businesses donate brankets and clothes to poor people. Meanwhile, 6 ( 8 percent) respondents indicated that they provide a feeding scheme for the community, while 2 (2.3 percent) indicated that they offer bussaries to university students and 3 (3.4 percent) respondents are not doing anything for the community.

\section{Conclusions}

The response rate of the study was $73 \%$. Cronbach's alpha was used to measure the inter-item consistency and to determine the normality of the data. The empirical findings on demographic variables were presented using figures, tables and charts. An important factor to note is the significant number of similarities in responses from participants. The findings also revealed that there is a significant positive relationship between objectives. Pearson correlation was used to determine the relationship between the questions.

\section{Recommendations for SMEs}

It has been indicated that the poor product quality is a result of the lack of managerial skills, and it puts more emphasiz on the perceptions of the customers against the product quality (Abdulai, 2014). However, Erol (2015, p. 123) considers that it is the poor service delivery to the customers that causes a big dent because of lack of skilled staff within the SMEs. Therefore, the findings of this study again indicated that $93 \%$ of the SMEs failed to survive because of constraints of the financial support from financial institutions to boost their SMEs (Makina, Fanta, Mutsonziwa, Khumalo, and Maposa 2015, p. 5). Marnewick (2014) agrees and concludes with the findings that the SMEs managers don't offer training to the staff in respect of getting to know about the features for the product. However, the findings of this study do not strongly suggest the same issues. Therefore, based on this comparison, the study concludes that all objectives were achieved and found to be realistic.

\section{Recommendations for further study}

The study recommends further research on the progress of implementation strategies that can be employed to improve automotive SMEs in the Durban metropolitan areas.

\section{References}

1. Abdulai, D.N. (2014). African-Centered Management Education: A new Paradigm for an Emerging Continent. Gower Publishing Limited.

2. Abdullah, A.M.N.D. and Rozario, F. (2009). Influence of Service and Product Quality towards Customer Satisfaction: A Case Study At the Staff Cafeteria in the Hotel Industry, International Journal of Social, Behavioral, Educational, Economic, Business and Industrial Engineering, 3(5).

3. Abor, J. and Quartey, P. (2010). Issues in SME Development in Ghana and South Africa, International Research Journal of Finance and Economics.

4. Agyekum, C.K., Haifeng, H. and Agyeiwaa, A. (2015). Consumer Perception of Product Quality, Microeconomics of Competitiveness, 3(2), pp. 25-29. Doi: 10:5923/j.m2economics.2015302.01

5. Amini, P., Falk, B. and Schmitt, R. (2014). Quantitative Analyzis of the Consumer Perceived Value Deviation, PayamAmini et al./Procedia CIRP 21. Available at: https://www.researchgate.net/publication/272823880 Quantitative_Analysis_of_the_Consumer_Perceived_Value_Deviation.

6. Bouazza, A.B., Ardjouman, D. and Abada, O. (2015). Establishing the Factors Affecting the Growth of Small and Medium-sized Enterprises in Algeria, American International journal of Social science, 4(2).

7. Breetzke, K. (2009). From Conceptual Framework to Quantitative Models: Spatial planning in the Durban metropolitan area, South Africa - the link to housing and infrastructure planning: Case study prepared for planning Sustainable Cities, Global Report on Human Settlement 2009. Available at: https://unhabitat.org.

8. Dash, A. and Tripathy, S. (2016). Journey of Quality Management Practices towards $21^{\text {st }}$ Century, International Journal of Management \& Business Studies, 6(2), pp. 2231-2436. Available at: http://ijmbs.com.

9. Deros, B., Yusof, S. and Salleh, A. (2006). A benchmarking implementation framework for automotive manufacturing SMEs, An International Journal, 13(4), pp. 396-430. Available at: http://www.emeraldsight.com/1463-5771.htm.

10. Doh, S. and Hwang, J. (2009). How Consumers Evaluate eWOM (Electronic Word -of-Mouth) Messages, CyberPsychology \& Behaviour, 12(2), pp. 193-197.

11. Duffet, R.G. and Wakeham, M. (2016). Social media marketing communication effect on attitudes among millennials in South Africa, The African Journal of Information System, 8(3). Available at: http://digitalcommons.kennesaw.edu/ajis.

12. Fouad, M.A.A. (2013). Factors affecting the performance of Small and Medium Enterprise (SMEs) in the manufacturing sector of Cairo, Egypt, International Journal of business and management studies, 5(2), pp. 1309-8047.

13. Frank, B., Torrico, B.H., Enkawa, T. and Schvaneveldt, S.J. (2014). Affect versus Cognition in the Chain from Perceived Quality to customer Loyalty: The Roles of Product and Experience, Journal Retailing, 90(4), pp. 567-586. Available at: http://dx.doi.org/10.1016/j.jretai.2014.08.001.

14. Gibbet, M., Leibold, M. and Probst, G. (2002). Five Styles of Customer Knowledge Management, and how Smart Companies Use Them To Create Value, European Management Journal, 2(5), pp. 459-469. 
15. Jahanshahi, A.A.J., Gashti, M.A.H., Mirdamadi, S.A., Nawaser, K. and Khaksar, S.M.S. (2011). Study the effects of Customer Service and Product Quality on Customer Satisfaction and Loyalty, International Journal of Humanities and social Science, 1(7). Available at: http://www.ijhssnet.com.

16. Kambwale, J.N., Chisoro, C. and Karodia, A.M. (2015). Investigation into the causes of small and medium enterprise failures in Windhoek, Namibia, Arabian journal of Business and Management Review, 4(7).

17. Khan, A. (2014). Government funds Available to SMEs in South Africa, GAA Accounting.

18. Khan, R.A.G., Khan, F.A. and Khan, M.A. (2011). Impact of Training and development on Organizational Performance, Global Journal of Management and Business research, 11(7).

19. Lamb, C.W., Hair, J.F., McDaniel, C, Boshoff, C. and Terblanche, N.S. (2008). Marketing, Perception. $3^{\text {rd }}$ ed. Oxford New York: Oxford University Press Southern Africa.

20. Lekhanya, L.M. (2006). Consumer perception of charity shops in the Durban Area, MTech Thesis Durban University of Technology.

21. Lekhanya, L.M. (2010). The use of Marketing Strategies by Small, Medium, and Micro Enterprises in Rural KwaZulu Natal, DTechThesis, Durban University of Technology.

22. Manyaka, S.J. (2015). Social entrepreneurship: A solution for transforming the disadvantaged community of Nellmapius. Available at: http:// www.hts.org.za/

23. Marnewick, C. (2014). Information and Communication township technology adoption amongst township micro and small business: The case of Soweto, South African Journal of Information, 16(1). Available at: http://sajim.co.za orhttp://doi:104102/sanjim.v16i1.618

24. Mbawuni, J. and Nimako, S.G. (2015). Predicting Clients' Intentions to Acquire Credit Facilities in Ghananian Financial Market, International Journal of Economics and Finance, 7(2).

25. Mbonyane, B.L. (2006). An exploration of factors that Lead to Failure of Small Business in the Kagiso Township, College of Economic and Management Sciences.

26. Meyn, M. (2004). The Export Performance of the South African Automotive Industry. New Stimuli by the EU-South Africa Free Trade Agreement? Institute for World Economics and International Management.

27. Moslehpour, M., Aulia, A.K. and Masarie, C.E.L. (2015). Bakery by Product Perception and Purchase Intention of Indonesian Consumers in Taiwan, International Journal of Business and Information, 10(1).

28. Naude, M.J. (2013). Supply chain challenges in the South African automotive sector: Do location, size and age matter, South African Journal of Economic and Management Sciences, 16(4), pp. 407-417.

29. Neneh, N.B. (2014). Determining high quality SMEs that significantly contribute to SME growth: regional evidence from South Africa, Problems and Perspectives in Management, 12(4).

30. Olawale, F. and Garwe, D. (2010). Obstacles to the growth of new SMEs in South Africa: A principal component analyzis approach, African Journal of Business Management, 4(5), pp. 729-738.

31. Papulova, Z. and Morkos, M. (2007). Importance of managerial skills and knowledge in management for small entrepreneurs.

32. Raji, M.N. and Zainal, A. (2016). The effect of customer perceived value on customer satisfaction: A case study of Malay upscale restaurants, Malaysian Journal of Society and Space, 12(3).

33. Rani, P. (2014). Factors influencing consumer behavior, International Journal of Current Research and Academic Review, 2(9), pp. 52-61.

34. Rose, A.M.N., Deros, B., Rahman, M.N. and Nardin, N. (2011). Laen manufacturing best practices in SMEs, Proceedings of the 2011 International Conference on IndustrilaEnginnering and Operations Management Kuala Lumpur, Malaysia.

35. Rudansky-Kloppers, S. (2014). Investigation Factors Influencing Customer Online Buying Satisfaction in Gauteng, South Africa, International Business \& Economic Research Journal, 13(5).

36. Ryu, K., Shin, J.,Lee, S. and Choi, H. (2008). I-Manufacturing Project for Collaboration-Based Korean Manufacturing Innovation.

37. Sarwar, A., Azam, S.M.F., Haque, A., Sleman, G. and Nikhashemi, S.R. (2013). Customer's Perception Towards Buying Chinese Preducts: An Empirical Investigation in Malaysia, Word Applied Sciences Journal, 22(2), pp. 152-160.

38. Singh, M. (2012). Marketing Mix of 4P's for Competitive Advantage, IOSR Journal of Business and Management, pp. 40-45. Available at: www.iosrjournals.org/

39. Sithole, M.L. (2015). The relationship between service and product quality, and SME success in South Africa, University of Witwatersrand.

40. Spence, M. and Essoussi, L.H. (2010). SME brand building and management: an exploratory study, European Journal of Marketing, 44(7/8), pp. 1037-1054. Available at: www.emeraldinsight.com/0309-0566.htm/

41. Tsele, L. (2015). Female entrepreneurship: Is South Africa winning the gender inequality struggle?

42. Vallab, D., Radder, L. and Venter, D. (2015). Factors preceding CRM readiness in small and medium -sized tourism tourismentreprise, AOSIS Open Journals. Available at: http://dx.doi.org/104102/ac.v15i1.263/

43. Veerappan, N.V.P and Sathishkumar. (2016). Impact of Industrial Policy of Small Scale Industries (ISS): An Exploratory study on Indian SSI'S, International Journal of Advanced Engineering Technology, 7(2).

44. Withers, S., Garza-Reyes, J.A., Kumar, V. and Roch-Lona, L. (2013). A Case study Improvement of a Testing Process by Combining Lean Management, Industrial Engineering and Automation Methods, International Journal of Engineering and Technology Innovation, 3(3), pp. 134-143. 